北原啓司 [弘前大学教育学部住居学研究室 助教授] 伝統的建造物群保存地区については，全国でその存続をめぐる話 題が取りざたされ，単に建築史的な問題ではなく，都市計画と連携 する課題となってきている。筆者らが，そのような現況の中で，「環 境管理」という概念を定義し，修理・修景，環境維持，教育という 3点から捉えようとしていることを評価したい。しかし，一般市民に 対するアンケート調查を実施したために，地域住民に対するアン ケート分析がやや浅くなってしまった感がする。地域住民と市民と の認識の違いは，調查をするまでもなく自明であり，むしろ，地域 住民のライフスタイル，㐫るいは将来イメージと，「環境管理」との 関係性を，明らかにするような深みのあるアンケートが欲しかった ところである。当事者にはデリケートな話題ではあるが，そこを通 ク過ぎることはできず，また，そのような質問調查自体が，筆者ら の規定する「教育」になると思われる。
益田兼房 [東京芸術大学大学院美術研究科 教授 ·工博] 最近の西欧での文化遺産研究では，都市内外の人文的自然環境を CULTURAL LANDSCAPE（文化的景観）と把握し，その歴史的 景観形成過程に総合的洒值を発見する動きが新しい。弘前市仲町地 区の場合，東北地方の武家屋敷の町並みで，武家住宅は少ないが屋 敷を囲むサワラ垣や庭園が多く残り，町並み景観の中での人文的自 然の役割が大きかった。この論文では，歴史的町並みの環境管理の なかでも生垣などの維持管理, 特にそれを担う地域住民の参加の重 要性に着目し，アンケート調査等により保存意識や管理の塞態を把 握し, 改善施策などを提案している。この論文が町並みの環境を管 理する「ひと」の重要性に着目したのは新鮮で，今後の保存計画の 改訂等，具体的な政策展開に墼がることを期待したい。住民参加型 の町並み保存は, 全国町並み保存連盟が 2000 年に採択した「町並み 憲章」でも中心的な概念で，都市型の保存会組織の形成も期待され る。

\title{
市街地縁辺にある公園構想の見直しから都市計画決定までのプロセス 共有化された目標像の実現化に向けた枠組みの提案
}

今野 亨, 小林英嗣 257

出口＼cjkstart敦［九州大学大学院人間環境学研究院都市・建築学部門 助教授・工博]

本研究は，都市計画マスタープランの実効性や担保性があいまい となる課題を踏ま之，地方都市に扮ける都市マスの役割と活用方法 に関する計画技術について，運動公園整備を具体例として実証的に 論じたものである。法改正から市町村の都市マス策定ブームが一段 落した今日，策定後の実効性や運用方法が問われている。本論では， 都市マスは公園等の個別の事業における住民参加のプロセスで目標 像の共有，事業推進の拠り所となる指針となり得，都市マスの実効 性は運用の如何で発揮されることを実証している。

但し，うまく運用される背景には，都市計画専門家等の役割や住 民参加の組織運営等に関する社会的技術やノウハウがあることも推 測される。都市マスが机上の計画とならず，その実効性が発揮され， 意味のある計画になっていく上で必要な社会技術とは何かに興味か そそられる。本論に付随する関連テーマについての成果も今後共有 していく必要がある。
野嶋慎二 [福井大学工学部建築建設工学科 助教授・工博] 都市計画マスタープラン（都市マス）と個々のプロジェクトとを いかに整合させていくかは，これらを扱う行政の担当部署の違いも あって大きな課題であり，今後重要なテーマとなるであろう。これ に対し中標津町の事例では, 都市マスからの継続性のある住民参加 によって長期的なまちづくりの目標像や当面の課題を確認しながら 計画策定に取り組み,プロジェクトの具体的な配置計画まで行った。 すなわち都市マスで共有化された目標像の赛現化を担保する段階ま で達したことは高く評価できる。そして本論文ではその計画プロセ スと体制がダイナミックに変化する状況を図や表などを用いて記録 に残しており，都市計画技術として資料的にも扔もしろい。今回の 論文の範囲を超えてしまうが,「地方都市における目標像の実現化に 向けた提案」について，コンサルタントの役割や継続的に関わるこ とができる仕組みなどを含めた詳細な提案が分かればさらに参考に なると考えられる。
塩崎賢明 [神戸大学工学部建設学科 教授・工博] 本研究は, 中国唐山地震 (1976 年) の被害と住宅復興の過程をト レースし, 阪神・淡路大震災の場合との比較考察を行ったものであ る。その復興は，旧市内だけでなく郊外に新たな都市地域を形成し たものであるが，(1)住宅および医療・教育施設の德興をインフラ復 旧とあわせて行ったこと，(2)国家資金の投入が大であるが，それだ けでなく，税制優遇などによる自助努力も促したこと，(3)都市の再 建にあたって集中を避け， 3 地区の分散型配置を取ったこと，に特徵 がある。

またっこうした復興に対して,アンケート調查では住民の 7 割以上 が満足を表明していることも明らかとなった。

本研究は，デー夕の少なかった唐山地震の復興過程を丁寧に記述 するだけでなく，被災住民に対してアンケート調查，ヒヤリング調 查などを行ない住民の意識についても明らかにした点で貴重な資料 を提供するものとなっている。
大西一嘉 [神戸大学工学部建設学科大西研究室 助教授・工博] 歴史的な大被害をもたらした唐山地震後の住宅復興について, 中 国有数の炭鉱都市唐山の中核的国有企業であった鉱務局の開濼地区 を対象とした事例調査をもとにした住宅再建についての報告であ る。現地の研究者も参画した研究であるが, 復興団地計画立案の背 景にまでは議論が踏み込んでいない点や, 最後のまとめの記述内容 が包括的すぎて現地で住民アンケートを実施した意図があいまいに なってしまっている点, 住民意識調查の処理や分析についてもやや 不十分さを感じる点が少なくないが，これまで余り知られることの なかった唐山地震後の地域レベルでの再建プロセスを知る上で意義 のある報告といえる。阪神淡路大震災後も, 台湾やトルコなど世界 各地で大規模地震が続いており, 様々な視点から海外復興事例の調 查が精力的に行なわれるようになってきた。本研究が一つの契機と なって，世界の歴史的災害の復興過程についても今後一層の解明が 進むことを期待したい。 